\title{
Green Power in the Garden: A Simple Water Feature Using Photovoltaic Solar Panels ${ }^{1}$
}

\author{
Edmund Lee Thralls²
}

This publication is intended to provide basic information about photovoltaic technology and a do-it-yourself project using a solar panel to provide power to a small water feature in a garden.

\section{Background}

Photovoltaic (PV) systems convert light energy directly into electricity. The PV effect (the operating principle of the solar cell) was discovered in 1839 by a French physicist, Alexandre-Edmond Becquerel, when he observed that certain materials would produce small electric currents when exposed to light. In 1870, Heinrich Hertz extended the research and improved upon the conversion efficiency by using solid selenium to create PV cells (Selinger and Barrow 2017). In 1905, Albert Einstein published a paper advancing the hypothesis that light energy is carried in discrete quantized packets to explain experimental data from the PV effect. The first practical solar cell was demonstrated in 1954 by Bell Telephone scientists Daryl Chapin and Gerald Pearson and chemist Calvin Fuller (Chodos 2009).

\section{Introduction}

In the 1950s, the US population emerged from multiple wars searching for ways to enjoy their return to peace and prosperity. A rise in home ownership and a do-it-yourself attitude contributed to the development of the suburban backyard with a patio and grill (Smithsonian 2019).
The nine principles of the Florida-Friendly Landscaping $^{\text {Tw }}$ program can assist homeowners in their backyard recreation. These principles are used to educate homeowners about how to design, install, and maintain healthy landscapes that use a minimum of water, fertilizer, and pesticides. The resulting landscapes are low-cost, lowmaintenance, and attractive, they add value to the community, and they reduce the chance of polluting the water supply (UF/IFAS 2015).

The Landscape Planning Worksheet in The Florida Yards $\&$ Neighborhoods Handbook - 2015 promotes a thriving, low-maintenance landscape adjustable to differing needs. It recommends that when drawing an activity map, homeowners should include an outdoor lighting/electrical plan to entertain and enjoy their landscape into the evening hours. Consider pathway lighting, water fountains, lighting in the garden shed, and power to radios, televisions, and fans as well as other "comfort accessories."

In the landscape and/or garden, most electrical applications can be met with low-voltage 12-volt DC power, including pathway lights, fountain pumps, landscape backlighting, outdoor fans, background music, etc. Storage batteries will not only store the power but will provide the power to each circuit as needed. Charging the battery can be accomplished using a solar panel.

1. This document is ENH1307, one of a series of the Environmental Horticulture Department, UF/IFAS Extension. Original publication date April 2019. Visit the EDIS website at https://edis.ifas.ufl.edu for the currently supported version of this publication.

2. Edmund Lee Thralls, Extension agent III, Environmental Horticulture Department, UF/IFAS Extension Orange County, Orlando, FL 32812.

The Institute of Food and Agricultural Sciences (IFAS) is an Equal Opportunity Institution authorized to provide research, educational information and other services only to individuals and institutions that function with non-discrimination with respect to race, creed, color, religion, age, disability, sex, sexual orientation, marital status, national origin, political opinions or affiliations. For more information on obtaining other UF/IFAS Extension publications, contact your county's UF/IFAS Extension office. 


\section{Photovoltaic Fundamentals}

The word photovoltaic comes from "photo," which refers to light, and "voltaic," which refers to producing electricity. Photovoltaic (PV) technology uses solar cells, electrical devices that convert energy from the sun directly into electricity. Individual solar cells are not very useful because they generate approximately 0.5 volts of electricity. To produce useable quantities of electricity, many solar cells are connected together to form a PV module, which generates many volts of electricity. These PV modules can then be linked together to form a PV array to meet the high electrical energy needs of the end user or application (Li 2011).

The four primary components for producing electricity using solar power are the solar panel, charge controller, battery, and inverter (Nalagon n.d.). Solar panels charge the battery. The charge controller regulates proper charging of the battery. The battery provides direct current (DC) voltage to an inverter. Finally, the inverter converts the DC voltage to normal alternating current $(\mathrm{AC})$ voltage.

Solar cells change light energy into electrical energy through the PV effect. The PV effect happens when light particles called photons energize electrons, causing the electrons to move and produce a current flow, which can be used to operate electrical devices (Parry-Hill, Sutter, and Davidson 2002).

Although electricity can be a difficult topic, knowing how the PV system works will help when dealing with problems. A gardener can grasp the fundamentals and conduct basic troubleshooting of low-voltage 12 -volt DC systems with a little information.

Solar panels are directed at solar south in the northern hemisphere and solar north in the southern hemisphere (these are slightly different than magnetic compass northsouth directions) at an angle dictated by the geographic location and latitude of where they are to be installed (Schaeffer 2007). Panels can be installed on a tall pole or a fence with an unobstructed line of sight toward the sun during daylight hours. Many solar arrays are placed at an angle equal to the site latitude (e.g., a 30-degree angle for $30^{\circ} \mathrm{N}$ latitude) with no bias for seasonal periods.

\section{Electrical Safety}

Electrical hazards can appear when least expected. Electrical shock occurs when electrical current travels through the body to ground. Sometimes this happens when a wire comes loose or the insulation is scraped off the electrical conductors. A fuse or circuit breaker are safety devices that should prevent this from happening. This is not as great of concern with low-voltage 12-volt DC circuits. Disconnect the power source before working on any electrical device. Routinely check electrical systems for loose connections and damage or scraped insulation. Ensure each circuit breaker and/or fuse is of the correct rating for the circuit it protects. If one is not sure, contact a licensed electrician to check the circuits (UCF n.d.).

\section{Do-It-Yourself Water Feature in the Home Garden}

At the UF/IFAS Extension Orange County Exploration Gardens, a water feature (Figure 1) is a beneficial addition to the Pollinator Garden. It provides water for wildlife as well as visual and audible enhancement for visitors to the gardens.

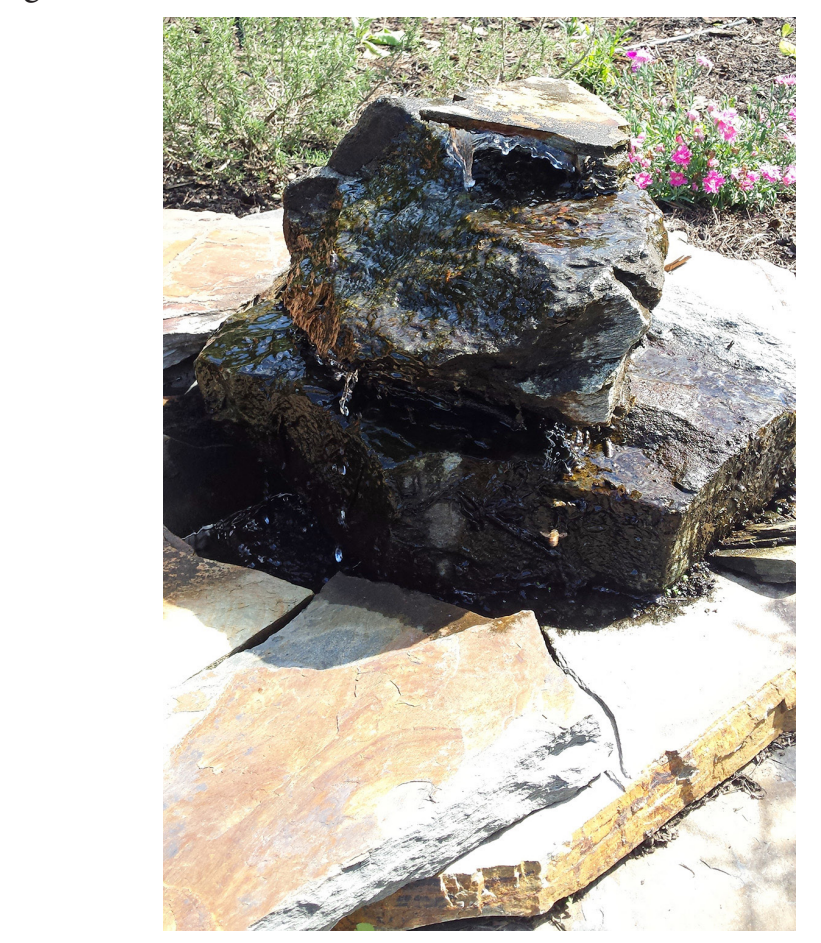

Figure 1. Water feature.

Credits: E. Thralls, UF/IFAS

Construction of the water source is relatively straightforward. At a suitable location, dig a hole three feet in diameter and about eighteen inches deep. Insert a pond liner extending about one foot outside the hole. Place a large bucket upside down near the center of the hole and on top of the liner. Fill the newly formed reservoir with water and check for leaks.

Once satisfied that the pond liner doesn't leak, obtain flagstone and several large granite rocks that can be stacked upon one another from a local vendor. Have the vendor 
drill $1 / 2$ " diameter holes through each of the granite rocks. Make sure that when the granite rocks are stacked on each other, the holes line up. Place flagstone on top of the liner that extends beyond the water reservoir, then place additional flagstone extending from the previously installed flagstone to the bucket in or near the center of the reservoir. Leave an opening to access the reservoir. Over the bucket, stack two or three granite rocks that have previously been drilled to accept a $1 / 2$ " diameter flexible tubing (Figure 2). The $1 / 2$ " outside diameter tubing will be the pathway from the reservoir to the top of the water feature.

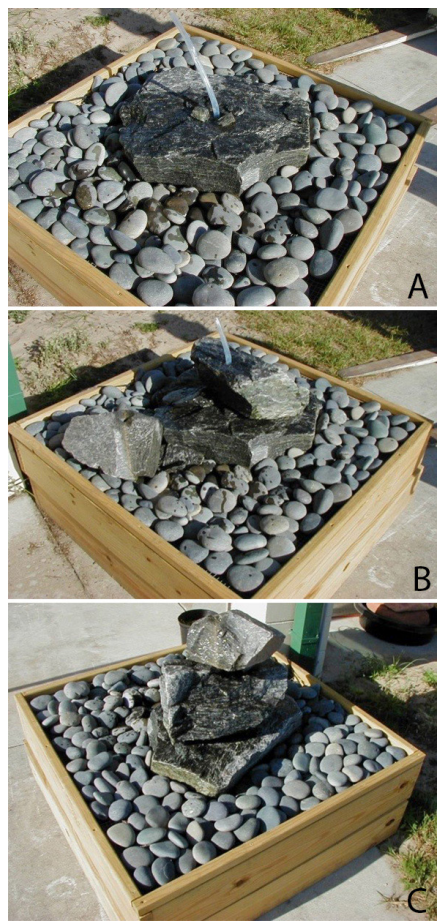

Figure 2. Stacking granite rocks and inserting water tube. A) First level; B) Second level; C) Third level.

Credits: E. Thralls, UF/IFAS

When deciding how to get the water from the bottom of the reservoir to the top of the water feature, a simple 12-volt DC pump, such as a bilge pump (Figure 4a) that might be used in a fishing boat live well, is an excellent choice. It is inexpensive, has a low power requirement, and can move the water to a height of 2-3 feet. Place the bilge pump in the water reservoir. Attach the $1 / 2$ " flexible tubing from bottom of the stacked granite rocks to the bilge pump outlet.

A cross-section diagram would look something like that seen in Figure 3.

The power used at the UF/IFAS Extension Orange County Exploration Gardens comes from three small 10-watt solar panels (Figures $4 \mathrm{a}$ and $4 \mathrm{~b}$ ). This power source is lightweight and unobtrusive in the garden, and it provides sufficient electrical energy to power the pump during daylight hours when visitors are touring the gardens.

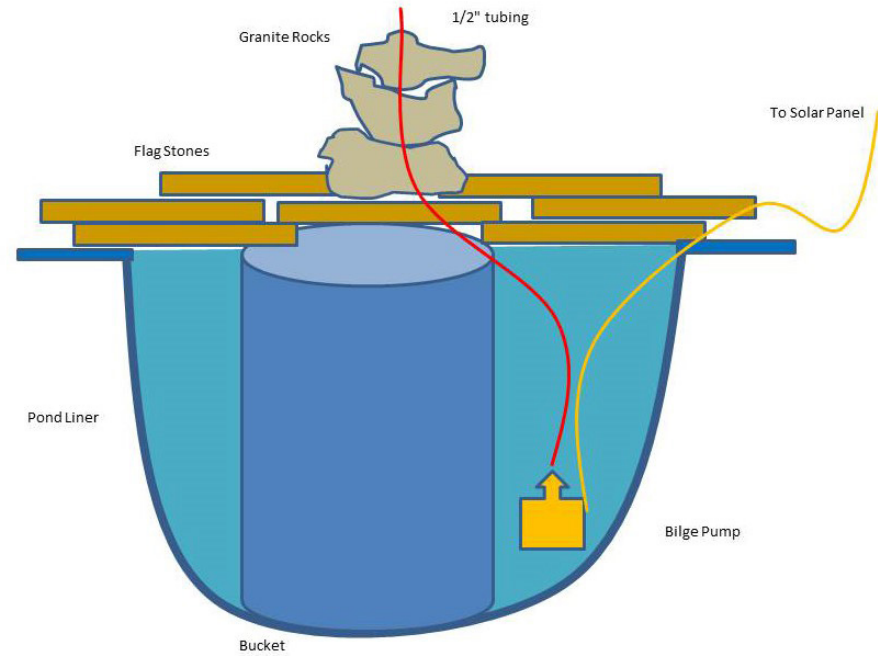

Figure 3. Cross-section of water feature. Credits: E. Thralls, UF/IFAS

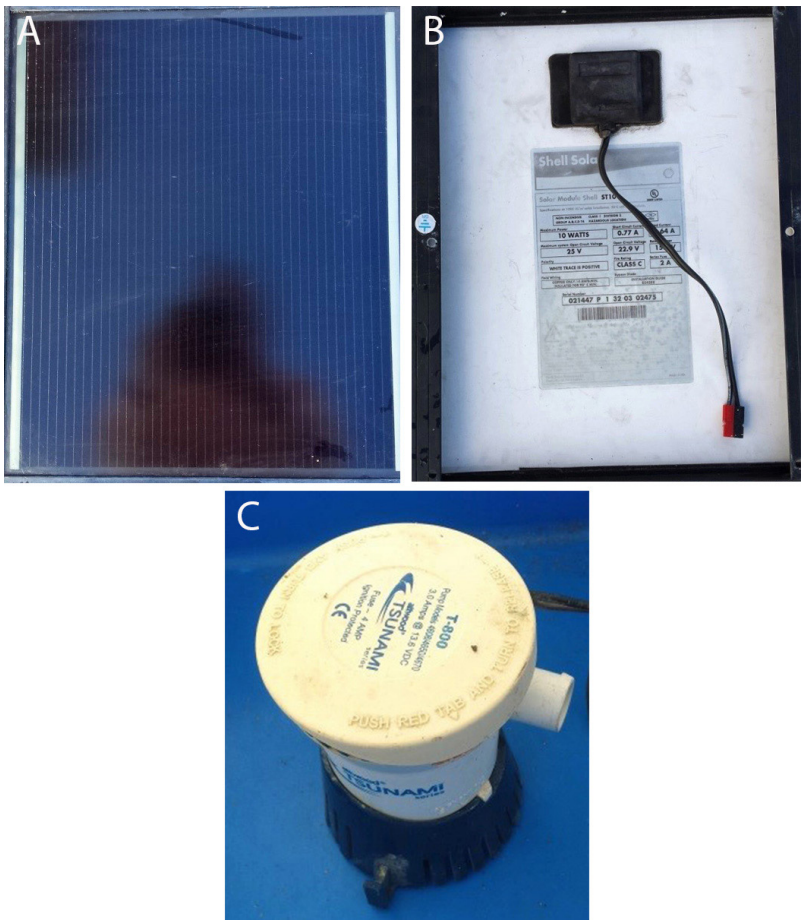

Figure 4. 10-watt solar panel and bilge pump. A) Solar panel front; B) Solar panel back; C) Bilge pump.

Credits: E. Thralls, UF/IFAS

The three solar panels are attached to a tall pole (a repurposed callbox donated by the Florida Department of Transportation) in the back of the garden (Figure 5). Any tall pole or a tall fence that places the solar panels in full sun facing a southerly direction will work. They provide more than 12 volts DC in full sunlight and are connected in parallel to provide the current (amps) to meet the bilge pump electrical specifications. 


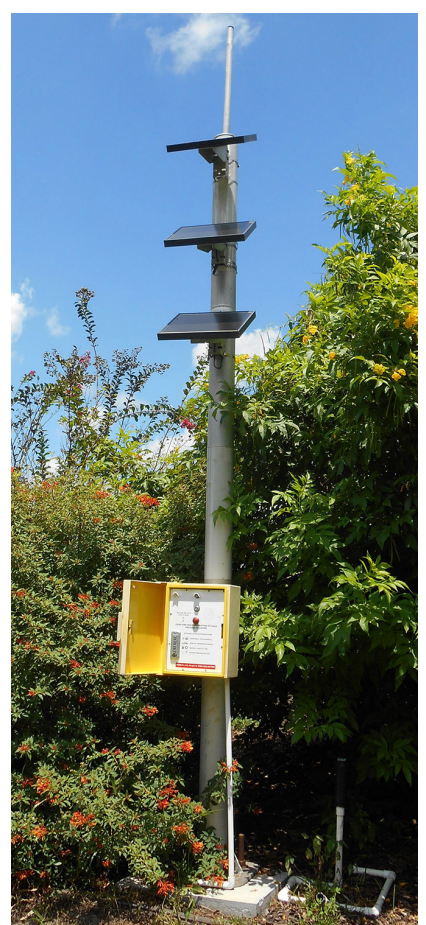

Figure 5. Repurposed DOT callbox.

Credits: E. Thralls, UF/IFAS

A $1 / 2$-inch schedule $40 \mathrm{PVC}$ pipe is placed at the base of the tall pole and extended to the water feature. The PVC pipe is then buried a few inches underground to protect the low-voltage power cables from being damaged by a shovel or hoe while working in the garden. Spray paint the PVC Pipe every few feet to keep from confusing it with a pipe carrying water. Extruded metal tubing (EMT) could be used but will rust over time in the soil. The insulated electrical cable is attached to the solar panel junction box in the repurposed callbox and then passed through the PVC pipe. The cable from the solar panels is then attached to the wires of the bilge pump. The solar panels will have negative and positive wires that need to be connected correctly to the negative and positive wires of the bilge pump so it will turn in the correct direction.

This water feature was installed in 2013 and still provides auditory and visual sensations in the gardens. Typical maintenance includes occasional cleaning of the water reservoir and replacement of the pump about every 2-3 years.

\section{References}

Chodos, Alan. 2009. "This Month in Physics History: April 25 ${ }^{\text {th }}$, 1954: Bell Labs Demonstrates the First Practical Silicon Solar Cell." APS News 18, no. 4 (April). https://www. aps.org/publications/apsnews/200904/physicshistory.cfm
Li, Yebo. 2011. Photovoltaic Systems for Solar Electricity Production. AEX-652. Columbus: Ohioline Ohio State University Extension. http://ohioline.osu.edu/factsheet/ AEX-652-11

Nalagon, Arnel. n.d. The Basics of Solar Power for Producing Electricity. http://www.academia.edu/26677817/ The_Basics_of_Solar_Power_for_Producing_Electricity

Parry-Hill, Matthew J., Robert T. Sutter, and Michael W. Davidson. 2002. "Solar Cell Operation." 10 Sept. 2018. http://micro.magnet.fsu.edu/primer/java/solarcell/

Schaeffer, John. 2007. Real Goods Solar Living Source Book-Special 30th Anniversary Edition: Your Complete Guide to Renewable Energy Technologies and Sustainable Living. Gabriola Island, BC: New Society Publishers.

Selinger, Ben, and Russell Barrow. 2017. Chemistry in the Market Place. Clayton South, Victoria, Australia: CSIRO Publishing. https://books.google.com/books?id=soYmDwAAQBAJ\&pg=PA374\&lpg=PA374\&dq $=1870$ s+\%E2\%80\%93+Hertz+developed+solid+selenium+PV\&s ource $=$ bl\&ots $=$ Ti_9c2B30b\&sig $=\mathrm{v}-\mathrm{me9jtXnHG8XJRuGIzg}$

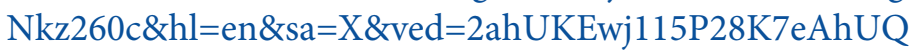
SN8KHag2CycQ6AEwAHoECAUQAQ\# $\mathrm{v}=$ onepage $\& \mathrm{q}=18$ 70s\%20\%E2\%80\%93\%20Hertz\%20developed\%20solid\%20 selenium $\% 20 \mathrm{PV} \& \mathrm{f}=$ false

Smithsonian Institution. 2019. "Patios, Pools, \& the Invention of the American Back Yard." https:// www.sites.si.edu/s/topic/0TO36000000L5NXGA0/ patios-pools-the-invention-of-the-american-back-yard

University of Central Florida. n.d. "Florida Solar Energy Center." 2019. http://www.fsec.ucf.edu/en/

UF/IFAS. 2015. "The Florida Yards \& Neighborhoods (FYN) Homeowner Program." Gainesville: University of Florida Institute of Food and Agricultural Sciences. http:// ffl.ifas.ufl.edu/homeowner.htm

UF/IFAS. 2015. The Florida Yards and Neighborhoods Handbook. Gainesville: University of Florida Institute of Food and Agricultural Sciences. http://ffl.ifas.ufl.edu/ materials/FYN_Handbook_2015_web.pdf 